\title{
PENERAPAN STRATEGI PEMBELAJARAN EKSPOSITORI PADA MATA PELAJARAN IPS DI KELAS IV SD NEGERI SARIBI
}

\author{
Yanto Rumbrawer, Beatus M. Laka, Maria Korwa
}

PGSD Sekolah Tinggi Keguruan dan Ilmu Pendidikan, Biak

\section{Kata Kunci :}

Strategi Pembelajaran Ekspositori

IPS

\begin{abstract}
The objectives of this research are 1) to describe the implementation of the expository learning strategy,, 2) to identify what efforts are being made to apply the expository learning strategy in the social studies subjects; 3) to describe the factors which becomes an obstacle in applying the expository learning strategy in the eyes of IPS students. The method used in this research is descriptive qualitative method. Data collection techniques used in the form of observation, interviews, questionnaires, and documentation. The results of this study shows the improvement of learning motivation.. The teacher guides the students in understanding the material and gives students the opportunity to ask questions. Quizzes are taken from the taught material or the material just learned and the teacher notices that they will be given a quiz at each meeting, so that students are better prepared for the quiz questions.
\end{abstract}

Email penulis:

lakamendelson@gmail.com

\begin{abstract}
ABSTRAK
Tujuan penelitian 1) Mendeskripsikan penerapan strategi pembelajaran ekspositori pada mata pelajaran IPS di kelas IV SD Negeri Saribi, 2) untuk mengetahui upaya-upaya apa yang dilakukan guna menerapkan strategi pembelajaran ekspositori pada mata pelajaran IPS, 3) untuk mendeskripsikan faktor-faktor yang menjadi kendala dalam penerapan strategi pembelajaran ekspositori pada mata pelajaran IPS. Metode yang digunakan dalam penelitian ini adalah metode deskriptif kualitatif. Teknik pengumpulan data yang digunakan berupa observasi, wawancara, angket, dan dokumentasi. Hasil penelitian ini menunjukan adanya peningkatkan motivasi belajar IPS. Guru membimbing siswa dalam memahami materi dan memberikan kesempatan kepada siswa untuk bertanya. Soal kuis diambil dari materi yang sudah diajarkan atau materi yang baru saja dipelajari serta adanya pemberitahuan dari guru bahwa akan diberikan kuis pada setiap pertemuan, agar siswa lebih siap menghadapi soal kuis.
\end{abstract}

\section{PENDAHULUAN}

Undang-udang No. 20 Tahun 2003 tentang sistem pendidikan nasional menyatakan bahwa pendidikan adalah usaha sadar dan terencana untuk mewujudkan suasana belajar dan proses pembelajaran agar peserta didik secara aktif mengembangkan potensi dirinya untuk memiliki kekuatan spiritual keagamaan, mengendalikan diri, kepribadian, kecerdasan, akhlak mulia, serta ketrampilan yang diperlukan dirinya, masyarakat, bangsa dan negara. 
Guru memegang peranan yang sangat strategis terutama dalam membentuk watak bangsa serta mengembangkan potensi siswa. Kehadiran guru tidak tergantikan oleh unsur yang lain, lebih-lebih dalam masyarakat kita yang multikultural dan multidimensional, dimana peranan teknologi untuk menggantikan tugas-tugas guru sangat minim. Guru yang profesional diharapkan menghasilkan lulusan yang berkualitas. Profesionalisme guru sebagai ujung tombak didalam implementasi kurikulum di kelas yang perlu mendapat perhatian (Depdiknas, 2005).

Dalam proses belajar mengajar, guru mempunyai tugas untuk mendorong, membimbing, dan memberi fasilitas belajar bagi siswa untuk mencapai tujuan. Guru mempunyai tanggung jawab untuk melihat segala sesuatu yang terjadi dalam kelas untuk membantu proses perkembangan siswa. Penyampaian materi pelajaran hanyalah merupakan salah satu dari berbagai kegiatan dalam belajar sebagai suatu proses yang dinamis dalam segala fase dan proses perkembangan siswa. Secara lebih terperinci tugas guru berpusat pada:

a. Mendidik dengan titik berat memberikan arah dan motivasi pencapaian tujuan baik jangka pendek maupun jangka panjang.

b. Memberi fasilitas pencapaian tujuan melalui pengalaman belajar yang memadai.

c. Membantu perkembangan aspek-aspek pribadi seperti sikap, nilai-nilai, dan penyesuaian diri, demikianlah dalam proses belajar mengajar guru tidak terbatas sebagai penyampaian ilmu pengetahuan akan tetapi lebih dari itu ia bertanggung jawab akan keseluruhan perkembangan kepribadian siswa ia harus mampu menciptakan proses belajar yang sedemikian rupa sehingga dapat merangsang siswa muntuk belajar aktif dan dinamis dalam memenuhi kebutuhan dan menciptakan tujuan. (Slameto, 1991:20)

Begitu pentingnya peranan guru dalam keberhasilan peserta didik maka hendaknya guru mampu beradaptasi dengan berbagai perkembangan yang ada dan meningkatkan kompetensinya sebab guru pada saat ini bukan saja sebagai pengajar tetapi juga sebagai pengelolah proses belajar mengajar. Sebagai orang yang mengelolah proses belajar mengajar tentunya harus mampuh meningkatkan kemampuan dalam membuat perencanaan pelajaran, pelaksanaan dan pengelolaan pengajaran yang efektif, penilain hasil belajar yang objektif, sekaligus memberikan motivasi pada peserta didik dan juga membimbing peserta didik terutama ketika peserta didik sedang mengalami kesulitan belajar.

Salah satu tugas yang dilaksanakan guru di sekolah adalah memberikan pelayanan kepada siswa agar mereka menjadi peserta didik yang selaras dengan tujuan sekolah. Guru mempengaruhi berbagai aspek kehidupan baik sosial, budaya maupun ekonomi. Dalam keseluruhan proses pendidikan, guru merupakan faktor utama yang bertugas sebagai pendidik. Guru harus bertanggung jawab atas hasil kegiatan belajar anak melalui interaksi belajar mengajar. Guru merupakan faktor yang mempengaruhi berhasil tidaknya proses belajar dan karenanya guru harus menguasai prinsip-prinsip belajar di samping menguasai materi yang disampaikan dengan kata lain guru harus menciptakan suatu kondisi belajar yang sebaik-baiknya bagi poeserta didik, inilah yang tergolong kategori peran guru sebagai pengajar.

Disamping peran sebagai pengajar, guru juga berperan sebagai pembimbing artinya memberikan bantuan kepada setiap individu untuk mencapai pemahaman dan pengarahan diri yang dibutuhkan untuk melakukan penyesuan diri secara maksimal terhadap sekolah. Hal ini sesuai dengan pendapat (Hamalik, 2002) yang mengatakan bimbingan adalah proses pemberian bantuan terhadap individu untuk mencapai pemahaman diri dan pengarahan diri 
yang dibutuhkan untuk melakukan penyesuaian diri secara maksimal terhadap sekolah, keluarga serta masyarakat.

Strategi pembelajaran Ekspositori adalah strategi pembelajaran yang menekankan kepada proses peyampaian materi secara verbal dari seorang guru kepada sekelompok siswa dengan maksud agar siswa dapat menguasai materi pelajaran secara optimal. Killen (1998) menanamkan strategi ekspositori ini dengan istilah strategi pembelajaran langsung (direct instruction). Mengapa demikian? Karena dalam strategi ini, materi pelajaran disampaikan langsung oleh guru. Oleh karena itu strategi ekspositori lebih menekankan kepada proses bertutur, maka sering juga dinamakan istilah "chalk and talk". Setiap individu yang diberi tugas atau kepercayaan untuk bekerja pada suatu organisasi tertentu diharapkan mampuh menunjukkan kinerja yang memuaskan dan memberikan konstribusi yang maksimal terhadap pencapaian tujuan organisasi tersebut.

Kinerja adalah tingkat keberhasilan seseorang atau kelompok orang dalam melaksanakan tugas dan tanggung jawabnya serta kemampuan untuk mencapai tujuan dan standar yang telah ditetapkan (Sulistyorini, 2001). Sedangkan Ahli lain berpendapat bahwa Kinerja merupakan hasil dari fungsi pekerjaan atau kegiatan tertentu yang di dalamnya terdiri dari tiga aspek yaitu: Kejelasan tugas atau pekerjaan yang menjadi tanggung jawabnya; Kejelasan hasil yang diharapkan dari suatu pekerjaan atau fungsi; Kejelasan waktu yang diperlukan untuk menyelesikan suatu pekerjaan agar hasil yang diharapkan dapat terwujud (Dale, 1992). (Fatah, 1996) Menegaskan bahwa kinerja diartikan sebagai ungkapan kemajuan yang didasari oleh pengetahuan, sikap dan motivasi dalam menghasilkan sesuatu pekerjaan.

Menurut Merton seperti dikutip oleh Koentjaraningrat (1985:21), bahwa konsep merupakan definisi dari apa yang perlu diamati. Dengan demikian dalam tahap ini perlu untuk memberikan batasan terhadap kedua variabel tersebut.

1. Strategi pembelajaran ekspositori

Strategi pembelajaran ekspositori adalah strategi pembelajaran yang menekankan kepada proses penyampaian materi secara verbal dari seorang guru kepada sekelompok siswa dengan maksud agar siswa dapat menguasai materi pelajaran secara optimal.

2. Pendidikan IPS

IPS merupakan ilmu-ilmu sosial yang dipadukan dan disederhanakan untuk tujuan pengajaran di sekolah. Dengan maksud menjadikan manusia yang dalam kehidupanya baik.

Dari beberapa penjelasan tentang pengertian kinerja di atas dapat disimpulkan bahwa kinerja guru adalah kemampuan yang ditunjukkan oleh guru dalam melaksanakan tugas atau pekerjaannya. Kinerja dikatakan baik dan memuaskan apabila tujuan yang dicapai sesuai dengan standar yang telah ditetapkan. Peran guru sebagai pengajar dan sebagai pembimbing memiliki keterkaitan yang sangat erat dan keduanya dilaksanakan secara berkesinambungan dan sekaligus berinterpenetrasi dan merupakan keterpaduan antara keduanya.

Terdapat beberapa hal penting dari konsep pendidikan menurut undang-undang tersebut. Namun dapat diambil bagian pertamanya yaitu, pendidikan adalah usaha sadar yang terencana, hal ini berarti proses pendidikan di sekolah bukanlah proses yang dilaksanakan secara asal-asalan dan untung-untung, akan tetapi proses yang bertujuan sehingga segala sesuatu yang dilakukan guru dan siswa diarahkan pada pencapaian tujuan. Hal ini berarti proses pendidikan berujung kepada pembentukan sikap, pengembangan kecerdasan atau 
intelektual, serta pengembangan ketrampilan anak sesuai dengan kebutuhan. Ketiga aspek (sikap, kecerdasan, dan keterampilan) arah dan tujuan pendidikan yang harus diupayakan.

Pembelajaran pada dasarnya adalah proses penambahan informasi dan kemampuan apa yang harus dimiliki oleh siswa, maka pada saat itu juga kita semestinya berpikir strategi apa yang harus dimiliki oleh siswa, maka pada saat itu juga kita semestinya berpikir strategi apa yang harus dilakukan agar semua itu dapat tercapai secara efektif dan efesien. Ini sangat penting untuk dipahami, sebab apa yang harus dicapai akan menentukan bagaimana caranya strategi pembelajaran yang diambil untuk materi pembelajaran IPS pada bagian ini adalah "strategi pembelajaran ekspositori" Strategi pembelajaran ekspositori merupakan bentuk dari pendekatan pembelajaran yang berorientasi kepada guru (teacher centered approach). Dikatakan demikian, sebab dalam strategi ini guru memegang peran yang sangat dominan. Melalui strategi ini guru menyampaikan materi pembelajaran secara terstruktur dengan harapan materi pelajaran yang disampaikan itu dapat dikuasai siswa dengan baik. Fokus utama strategi ini adalah kemampuan akademik (academic achievement) siswa. Metode pembelajaran dengan kuliah merupakan bentuk strategi ekspositori.

Dari latar belakang masalah yang telah diuraikan di atas maka dapat di angkat judul. Penerapan Strategi Pembelajaran Ekspositori Pada Mata Pelajaran IPS di Kelas IV SD Negeri Saribi Distrik Orkeri, Kabupaten Biak Numfor.

\section{METODE PENELITIAN}

Metode yang digunakan dalam penelitian ini adalah metode deskriptif kualitatif. Teknik pengumpulan data yang digunakan berupa observasi. Observasi adalah suatu metode untuk mengumpulkan data yang dilakukan dengan cara mengadakan pengamatan langsung terhadap objek penelitian yang meliputi kegiatan atau aktivitas pembelajaran di SD Negeri Saribi Distrik Orkeri Kabupaten Biak Numfor. Wawancara adalah, "Proses tanya jawab dalam penelitian yang berlangsung secara lisan bilamana dua orang atau lebih bertatap muka, mendengarkan secara langsung informasi-informasi atau keterangan-keterangan, angket atau kuisioner merupakan teknik pengumpulan data yang dilakukan dengan cara memberi pertanyaan atau pernyataan tertulis kepada responden untuk dijawabnya. Responden dalam penelitian ini adalah siswa-siswi Kelas IV SD Negeri Saribi Distrik Orkeri Numfor yang dijadikan sebagai pelaku utama dalam proses pembelajaran IPS.

Dengan teknik pengumpulan data ini peneliti berharap dapat mengetahui secara jelas tentang pelaksanaan strategi pembelajaran yang diterapkan oleh guru di SD Negeri Saribi Distrik Orkeri Kabupaten Biak Numfor, dan dokumentasi resmi terbagi atas dokumentasi internal dan dokumentasi eksternal. Dokumentasi internal berupa memo, pengumuman, instruksi, aturan satuan lembaga masyarakat tertentu yang digunakan dalam kalangan sendiri. Teknik Analisis yang digunakan yaitu teknik analisis deskriptif kualitatif. Untuk menganalisis data, penulis menggunakan metode deskriptif kualitatif, yang merupakan alat analisis data untuk mendeskripsikan hal-hal nyata yang ditemui dilapangan.

\section{HASIL DAN PEMBAHASAN 1. Perencanaan Pembelajaran}

Peneliti dan rekan peneliti mengamati proses Pembelajaran Ekspositori Pada Mata Pelajaran IPS di Kelas IV SD Negeri Saribi, Distrik Orkeri, Kabupaten Biak Numfor menggunakan lembar observasi yang telah disusun dengan aspek-aspek yang berhubungan dengan aktivitas siswa dan pemberian tugas pada saat pembelajaran menggunakan metode ekspositori untuk meningkatkan motivasi belajar siswa. 
Berdasarkan pengamatan pada pertemuan pertama, siswa masih belum terbiasa dengan pemberian tugas tetapi sudah menunjukkan rasa senang dengan adanya kuis, meskipun ada beberapa siswa yang bekerja sama dalam pemberian tugas. Pada saat pembelajaran berlangsung masih ada sebagian siswa yang terlihat berbicara sendiri dengan temannya. pembelajaran berlangsung terlihat bahwa siswa lebih antusias berdiskusi dengan teman sebangku saat mengerjakan latihan soal, meskipun ada beberapa yang terlihat malas mengerjakan. Siswa sudah mulai berani mengerjakan soal di depan meskipun tidak ditunjuk guru. Siswa juga sudah mulai terbiasa dengan pemberian kuis.

Pengamatan (observasi) ini dilakukan untuk mengatahui peningkatan motivasi belajar siswa terhadap Pembelajaran Ekspositori Pada Mata Pelajaran IPS di Kelas IV SD Negeri Saribi, Distrik Orkeri Kabupaten Biak Numfor dengan pemberian tugas. Tahap perencanaan diawali menyusun instrumen, yaitu Rencana Pelaksanaan Pembelajaran (RPP), Pembelajaran Ekspositori Pada Mata Pelajaran IPS di Kelas IV SD Negeri Saribi Distrik Orkeri-Numfor.

\section{Pelaksanaan Pembelajaran}

Tahap pelaksanaan merupakan kegiatan belajar mengajar di dalam kelas dengan setting sesuai rencana penelitian yang telah disusun. Pelaksanaan proses pembelajaran menggunakan metode ekspositori Pembelajaran Ekspositori Pada Mata Pelajaran IPS di Kelas IV SD Negeri Saribi Distrik Orkeri Kabupaten Biak Numfor.

Guru membimbing siswa dalam memahami materi dan memberikan contoh soal. Kemudian untuk mengetahui pemahaman siswa guru memberikan tugas yang dikerjakan secara mandiri oleh siswa dan hasilnya dikumpulkan untuk dinilai, soal hanya satu buah pada setiap kuis yang diberikan. Kuis diberikan setelah guru membimbing siswa dalam memahami materi pelajaran. Guru mengawasi saat para siswa mengerjakan kuis dan peneliti juga ikut membantu mengawasi.

Bila siswa telah selesai mengerjakan kuis, maka guru bersama-sama siswa membahas soal kuis. Kemudian guru memberikan latihan soal yang dikerjakan secara berdiskusi dengan teman sebangku. Apabila telah selesai mengerjakan latihan soal, guru menunjuk salah satu siswa untuk maju ke depan kelas. Selama siswa menjelaskan di depan kelas, guru dan siswa yang lain mendengarkan baik-baik, setelah selesai menjelaskan, barulah guru menanyakan apakah ada yang tidak setuju atau mungkin memiliki jawaban yang berbeda dengan jawaban siswa yang maju, bila ternyata ada yang memiliki pendapat yang berbeda, maka siswa tersebut dipersilahkan untuk memberikan pendapatnya di depan kelas juga. Setelah itu, guru menyimpulkan jawaban yang benar dan melanjutkan ke materi berikutnya.

Pada saat pembelajaran berlangsung, peneliti mengamati segala aktivitas yang terjadi selama proses belajar mengajar berlangsung, baik aktivitas siswa, maupun guru yang mengajar. Agar informasi yang diperoleh lebih akurat, maka peneliti telah mempersiapkan pedoman observasi untuk penyusunan catatan lapangan.

Peneliti melakukan diskusi dengan guru untuk menyimpulkan hasil pelaksanaan Pembelajaran Ekspositori Pada Mata Pelajaran IPS di Kelas IV SD Negeri Saribi, Distrik Orkeri, Kabupaten Biak Numfor. Data yang diperoleh selama observasi digunakan untuk mengetahui peningkatan motivasi belajar IPS siswa dengan pemberian tugas.

Permasalahan-permasalahan yang muncul selama pembelajaran berlangsung pada siklus I adalah sebagai berikut.

a. Beberapa siswa kurang aktif apabila guru menyuruh menyelesaikan soal di depan. Siswa yang maju didominasi oleh siswa yang pandai dalam menyelesaikan masalah. 
b. Kurangnya latihan soal, karena waktu terpotong untuk kuis dan menjelaskan materi pelajaran.

c. Kuis dikerjakan kurang optimal karena guru tidak memberitahukan kepada siswa pada pertemuan sebelumnya bahwa akan diberikan kuis pada setiap pertemuan materi matriks sehingga masih ada siswa yang bekerja sama saat menyelesaikan soal kuis.

d. Siswa belum memahami penjelasan guru, sehingga guru dan peneliti harus berkeliling untuk mengetahui pemahaman siswa.

e. Ketika mengerjakan latihan soal, masih ada siswa yang berbicara sendiri dengan temannya.

Dalam proses pembelajaran, dapat dikatakan bahwa motivasi belajar IPS siswa selama proses pembelajaran masih kurang optimal. Hal ini dikarenakan pada pertemuan sebelumnya guru tidak memberitahukan kepada siswa bahwa akan diberikan tugas pada setiap pertemuan. Hal ini juga menunjukkan motivasi belajar siswa kurang optimal.

\section{Evaluasi Pembelajaran}

Evaluasi yang dilakukan antara lain meliputi ketercapaian indikator pembelajaran, kendalakendala yang dihadapi selama tindakan berlangsung, respons siswa terhadap tindakan pembelajaran, melakukan evaluasi I berupa tugas kepada siswa berdasarkan soal-soal tes yang telah dipersiapkan sebelumnya.

Adapun beberapa permasalahan yang timbul selama proses pembelajaran berlangsung yang dapat dilakukan berdasarkan hasil evaluasi adalah sebagai berikut.

1. Dengan pemberian tugas, motivasi belajar siswa meningkatkan dan membantu guru untuk mengetahui tingkat pemahaman siswa.

2. Nilai tambahan yang diberikan oleh guru meningkatkan motivasi siswa untuk mengerjakan latihan soal dan mengerjakan soal di depan dengan benar.

3. Dengan dibahasnya latihan soal yang tidak dapat dikerjakan oleh siswa dan ditambahnya pemberian pekerjaan rumah, semakin menambah motivasi belajar siswa karena banyak latihan soal.

4. Guru memberitahukan kepada siswa untuk mengulang materi sebelumnya dan mempelejari materi berikutnya, karena setiap pertemuan akan diberikan kuis untuk meningkatkan motivasi belajar IPS.

5. Siswa lebih berkonsentrasi mengerjakan latihan soal dan tugas karena dipantau oleh peneliti dan guru.

Pada pelaksanaannya masih mengalami hambatan. Hambatan tersebut diantaranya adalah masih ada siswa yang bekerja sama atau membuka buku dalam menyelesaikan tugas IPS. Siswa merasa kesulitan dalam menentukan langkah-langkah bila tanpa bimbingan dari guru. Hal ini dikarenakan kurangnya waktu untuk membahas semua soal.

Berdasarkan pengamatan, baik dilihat dari perilaku dan keterampilan siswa yang ditunjukkan di kelas, pemberian tugas pada pembelajaran IPS. Hal ini disebabkan kesadaran siswa akan manfaat mempelajari mata pelajaran IPS menjadi lebih tinggi.

\section{Hasil Wawancara}

Berdasarkan hasil wawancara, siswa tertarik dengan pembelajaran menggunakan metode ekspositori dengan pemberian tugas mata pelajaran IPS. Siswa merasa semakin bersemangat 
dalam belajar IPS karena mereka merasa tertantang dengan latihan soal dan soal kuis yang diberikan. Bagi siswa, pembelajaran dengan pemberian kuis dapat meningkatkan pemahaman siswa dengan tidak membuka buku dan dikerjakan secara mandiri.

Beberapa siswa kurang menyukai pelajaran IPS karena mereka menganggap mata pelajaran IPS tidak menyenangkan. Sedangkan sebagian siswa berpendapat bahwa matematika menyenangkan karena soal latihannya membuat penasaran dalam mencari penyelesaiannya. Pada pembelajaran mata pelajaran IPS, siswa lebih memperhatikan dan keinginan untuk mempelajari mata pelajaran IPS menjadi lebih tinggi. Hal ini dikarenakan dorongan dan motivasi yang diberikan guru membuat siswa menjadi lebih senang dan tertarik terhadap mata pelajaran IPS, sehingga mendorong mereka untuk mata pelajaran IPS. Selain itu, siswa lebih nyaman dan senang karena guru memberikan kesempatan berdiskusi dengan teman sebangku saat mengerjakan latihan soal dan guru juga memberikan kesempatan untuk bertanya apabila siswa tidak dapat mengerjakan soal kuis. Guru lebih bersikap ramah dan bersahabat sehingga siswa tidak takut untuk bertanya atau mengerjakan soal di depan kelas.

Pembelajaran mata pelajaran IPS menggunakan metode ekspositori dengan pemberian mata pelajaran IPS, motivasi belajar siswa menjadi lebih meningkat. Pada akhir pembelajaran siswa semakin menyenangi dan berminat terhadap mata pelajaran IPS, meskipun pada awalnya siswa merasa kurang menyukai kuis karena pada saat mengerjakan kuis tidak boleh membuka buku.

\section{Pembahasan}

Berdasarkan hasil penelitian diperoleh pembelajaran ekspositori pada mata pelajaran IPS di kelas IV SD Negeri Saribi Disktrik Orkeri Kabupaten Biak Numfor dapat meningkatkan motivasi belajar IPS siswa. Metode pembelajaran ekspositori dengan pemberian kuis dapat juga meningkatkan minat, perhatian, rasa senang siswa, keinginan untuk mempelajari IPS. Pelaksanaan pembelajaran ekspositori pada mata pelajarn IPS di kelas IV SD Negeri Saribi dapat meningkatkan motivasi belajar sebagai berikut.

1. Guru menggunakan metode pembelajaran Ekspositori

Guru membimbing siswa dalam memahami materi dan memberikan kesempatan kepada siswa untuk bertanya. Dengan metode ekspositori ini siswa menjadi lebih aktif dalam pembelajaran dan siswa menjadi lebih berani dalam menyampaikan pertanyaan dan pendapat yang menumbuhkan rasa percaya diri. Hal ini disebabkan pembelajaran tidak lagi terpusat pada guru, siswa sudah diberi kesempatan untuk menyampaikan pertanyaan dan pendapat. Menurut Constance Frith dalam Motivation to Learn, dengan memberikan peluang atau kesempatan kepada siswa, maka siswa akan memperoleh kepercayaan diri mereka (http://www.usask.ca/education/coursework/802papers/ Frith/Motivation.HTM).

2. Guru memberikan contoh soal yang relevan dalam kehidupan sehari-hari

Dengan contoh soal yang relevan dalam kehidupan sehari-hari akan memudahkan siswa memahami materi yang diajarkan bahwa implementasi pembelajaran IPS berdasarkan realistik sekurang-kurangnya telah mengubah sikap siswa menjadi lebih tertarik terhadap pelajaran IPS.

Guru memberikan latihan soal kepada siswa yang dikerjakan dengan berdiskusi. Dalam diskusi siswa dapat berlatih kerja sama dan tanggung jawab dalam kelompoknya. Dengan demikian siswa dapat menemukan sendiri jawaban soal dan tidak tergantung pada guru serta siswa dapat menanggapi pendapat orang lain, dengan berdiskusi siswa terlibat aktif dalam proses belajarnya dan berkesempatan 
berlatih berani mengemukakan pendapat di depan umum secara sistematik serta dapat menanggapi pendapat orang lain.

3. Pemberian kuis yang dikerjakan oleh siswa secara mandiri dan close book

Dalam mengerjakan kuis, siswa tidak boleh membuka buku dan bekerja sama karena kuis digunakan untuk mengetahui tingkat penguasaan siswa terhadap materi yang telah atau baru diajarkan. Selain itu, kuis dapat merangsang siswa agar lebih termotivasi dalam belajar. Menurut Suryawahyuni (2008), teknik motivasi yang dapat dilakukan guru salah satunya dengan memberikan tugas dalam setiap kegiatan yang dilakukan, dimana siswa dalam melakukan tugasnya tidak bekerjasama dengan siswa yang lainnya. Dengan demikian siswa akan dapat membandingkan hasil pekerjaan yang dilakukannya dengan hasil siswa lainnya.

Peningkatan motivasi belajar pembelajaran ekspositori pada mata pelajaran IPS di kelas IV SD Negeri Saribi terlihat dari sikap siswa yang memperhatikan guru yang sedang menjelaskan, menjawab pertanyaan dari guru, rasa senang, keinginan yang besar dan ketekunan untuk menyelesaikan kuis dan soal. Hasil pengamatan yang didukung oleh hasil angket dan wawancara yang menunjukkan bahwa siswa senang dan berminat apabila diberikan kuis pada saat pembelajaran sehingga memotivasi siswa dalam belajar IPS.

\section{KESIMPULAN}

Berdasarkan hasil penelitian dan pembahasan dapat disimpulkan:

Pelaksanaan pembelajaran IPS dengan menggunakan metode ekspositori pada mata pelajarn IPS di kelas IV SD Negeri Saribi Distrik Orkeri Kabupaten Biak Numfor dapat meningkatkan motivasi belajar IPS sebagai berikut:

a. Guru membimbing siswa dalam memahami materi dan memberikan kesempatan kepada siswa untuk bertanya.

b. Soal kuis diambil dari materi yang sudah diajarkan atau materi yang baru saja dipelajari.

c. Adanya pemberitahuan dari guru bahwa akan diberikan kuis pada setiap pertemuan, agar siswa lebih siap menghadapi soal kuis.

\section{REFERENSI}

Depdiknas. (2005). Peraturan Pemerintah Republik Indonesia No. 19 Th. 2005 tentang Standar Nasional Pendidikan. Jakarta: Dep Dik Nas

Fatah. (1996). Landasan Manajemen Pendidikan. Bandung: Remaja Rosdakarya.

Koentjaraningrat. (1985). teknik pengukuran dan penelitian hasil belajar. Bandung: CV. Adira.

Suryawahyuni, Latief. (2008). Meningkatkan Motivasi Belajar. Jambi Ekspress Online.

Oemar H. (2002). Kurikulum dan Pembelajaran. Bumi Aksara: Jakarta.

Killen, Roy. (1998). Effective Teaching Strategies, Lessons From Research and Practice. Australia : social Science Press.

Slameto. (1991). Belajar dan Faktor-faktor yang mempengaruhinya. Bumi Aksara: Jakarta.

Silistyorini. (2001). Hubungan antara Keterampilan Manajerial Kepala Sekolah dan Iklim Organisasi dengan Kinerja Guru. http://www.duniaguru.com. 
Dale, T.A. (1992). Seri Sumber Daya Manusia. Jakarta: PT Elex Media Komputindo. UU No. 20 tahun 2003. Sistem Pendidikan Nasional. Jakarta

(http://www.usask.ca/education/coursework/802papers/Frith/Motivation.HTM). diambil/diunggah pada tanggal, 27 Juli 2017 